\title{
Atypical course of varicella-zoster infection in a child with acute lymphoblastic leukaemia
}

\author{
Nietypowy przebieg zakażenia wirusem ospy wietrznej i półpaśca \\ u dziecka z ostrą białaczką limfoblastyczną
}

${ }^{1}$ Department of Paediatrics with Observation Unit, Medical University of Warsaw, Warsaw, Poland

2 Department of Paediatrics, Haematology and Oncology, Medical University of Warsaw, Warsaw, Poland

${ }^{3}$ Students'Science Club, Department of Paediatrics with Observation Unit, Second Faculty of Medicine, Medical University of Warsaw, Warsaw, Poland

Correspondence: Magdalena Okarska-Napierała, Department of Paediatrics with Observation Unit, Żwirki iWigury 63 A, 02-091 Warsaw, Poland, tel.: +48 503 065 849, e-mail: magda.okarska@gmail.com

Abstract Varicella is a common, usually self-limiting, contagious childhood disease. Its clinical presentation in generally healthy children is characteristic enough to allow one to make a diagnosis; however, in immunosuppressed patients the diagnosis may be difficult due to atypical course of the disease. This article presents a diagnostically challenging case of a 5-year-old boy with newly diagnosed acute lymphoblastic leukaemia who developed varicella-zoster infection during induction steroid therapy, with an atypical, mild course without fever or pruritus, with eruptions of changed morphology. The presented case shows that in children with leukaemia who have been in contact with individuals with varicella, the occurrence of any rash should raise suspicion of the disease. In this group of patients the diagnostic method of choice is PCR test of skin eruption material. Intravenous acyclovir therapy should be started already before the PCR result comes back.

Keywords: diagnosis, varicella, zoster, leukaemia, immunosuppression

Streszczenie Ospa wietrzna jest występującą powszechnie, zaraźliwą, zwykle samoograniczającą się chorobą wieku dziecięcego. Jej obraz kliniczny u ogólnie zdrowych dzieci jest na tyle charakterystyczny, że wystarcza do postawienia diagnozy, jednak u chorych $\mathrm{w}$ immunosupresji rozpoznanie może być trudne ze względu na nietypowy przebieg. W niniejszej pracy przedstawiono stanowiący wyzwanie diagnostyczne przypadek 5-letniego chłopca ze świeżo rozpoznaną ostrą białaczką limfoblastyczną, u którego w trakcie steroidoterapii indukcyjnej rozwinęło się zakażenie wirusem ospy wietrznej i półpaśca o nietypowym, łagodnym przebiegu bez gorączki i świądu, z wykwitami o zmienionej morfologii. Prezentowany przypadek dowodzi, że u dzieci z białaczką skontaktowanych z chorym na ospę wietrzną pojawienie się jakiejkolwiek wysypki powinno nasuwać podejrzenie zachorowania. W tej grupie pacjentów badaniem diagnostycznym z wyboru jest PCR materiału $\mathrm{z}$ wykwitu. W trakcie oczekiwania na wynik należy rozpocząć leczenie dożylne acyklowirem.

Słowa kluczowe: diagnoza, ospa wietrzna, półpasiec, białaczka, immunosupresja 


\section{CASE REPORT}

A n almost 5-year-old boy hospitalised at a department of haematology and oncology for newly diagnosed acute lymphoblastic leukaemia (common B ALL) was transferred to an observation and isolation unit with suspected varicella. According to the patient's history, 2 weeks earlier the boy was referred to an oncologist with a suspected neoplastic disease due to persistent fatigue lasting a few weeks, strong pain of the legs lasting a few days, night sweats and skin pallor. Physical examination revealed skin and mucosal pallor, generalised lymphadenopathy, slight splenomegaly and numerous petechiae on the skin of the whole body. In laboratory tests, an elevated level of uric acid $(5.1 \mathrm{mg} / \mathrm{dL})$, increased activity of lactate dehydrogenase (943 IU/L), significant thrombocytopaenia $\left(16 \times 10^{3} / \mathrm{mm}^{3}\right)$, anaemia (Hgb $6.4 \mathrm{~g} / \mathrm{dL}, \mathrm{RBC} 2.25 \times 10^{6} / \mathrm{mm}^{3}$ ) and neutropenia $\left(290 / \mathrm{mm}^{3}\right)$ were found. Peripheral blood differential revealed a $32 \%$ proportion of blastic cells. Bone marrow analysis confirmed the diagnosis of acute lymphoblastic leukaemia. The patient started ALLIC 2009

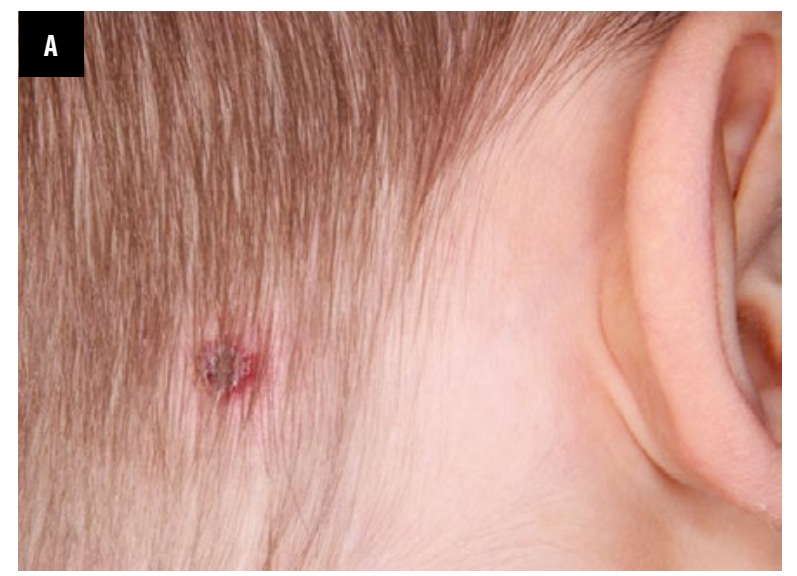

regimen (prednisone at $60 \mathrm{mg} / \mathrm{m}^{2}$ of body surface area). On the $4^{\text {th }}$ day of steroid therapy, on the scalp, on the right occipital area, the patient developed a small inflammatory infiltration of approximately $1.5 \mathrm{~cm}$ in diameter with erosion on top, which subsequently crusted over. After 2 days, a few erosions and a single vesicle with serous contents appeared on the skin of the trunk. Based on the patient's history it was determined that the boy attended preschool where cases of varicella appeared 3 weeks earlier. The patient had never had varicella before and was not vaccinated against the disease.

On the $2^{\text {nd }}$ day of having a rash the boy was transferred to an isolation and observation unit, where he was assessed to be in a good general condition. On physical examination, in the right occipital area a single movable nodule mentioned above was found which was of approximately $1.5 \mathrm{~cm}$ in diameter, had an erythematous bed and erosion covered with a yellow crust (Fig. 1). The retroauricular lymph node draining the area was enlarged and tender. On the skin of the chest, back, extremities, scrotum and penis there were single erosions without any associated inflammatory reaction. On the abdomen there was

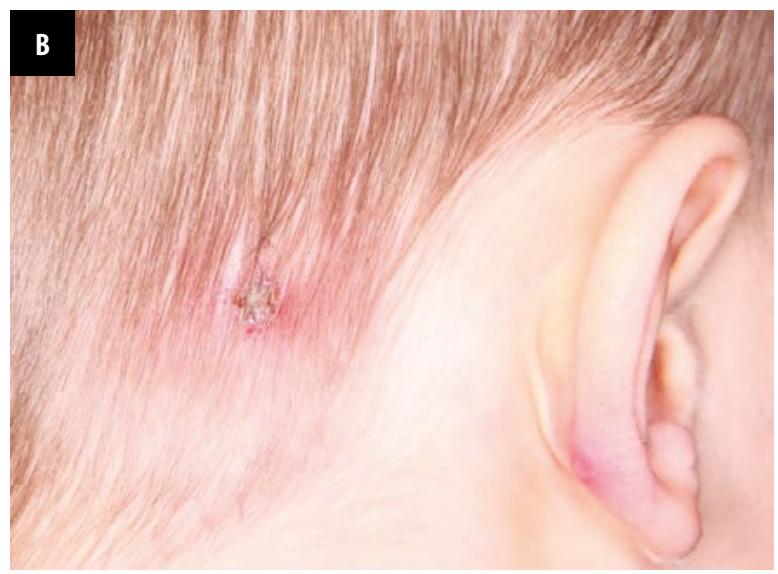

Fig. 1. Nodule on an erythematous bed, covered with a honey-like crust. Photographs taken on the $1^{\text {st }}(\mathbf{A})$ and $2^{\text {nd }}(\mathbf{B})$ day of acyclovir treatment
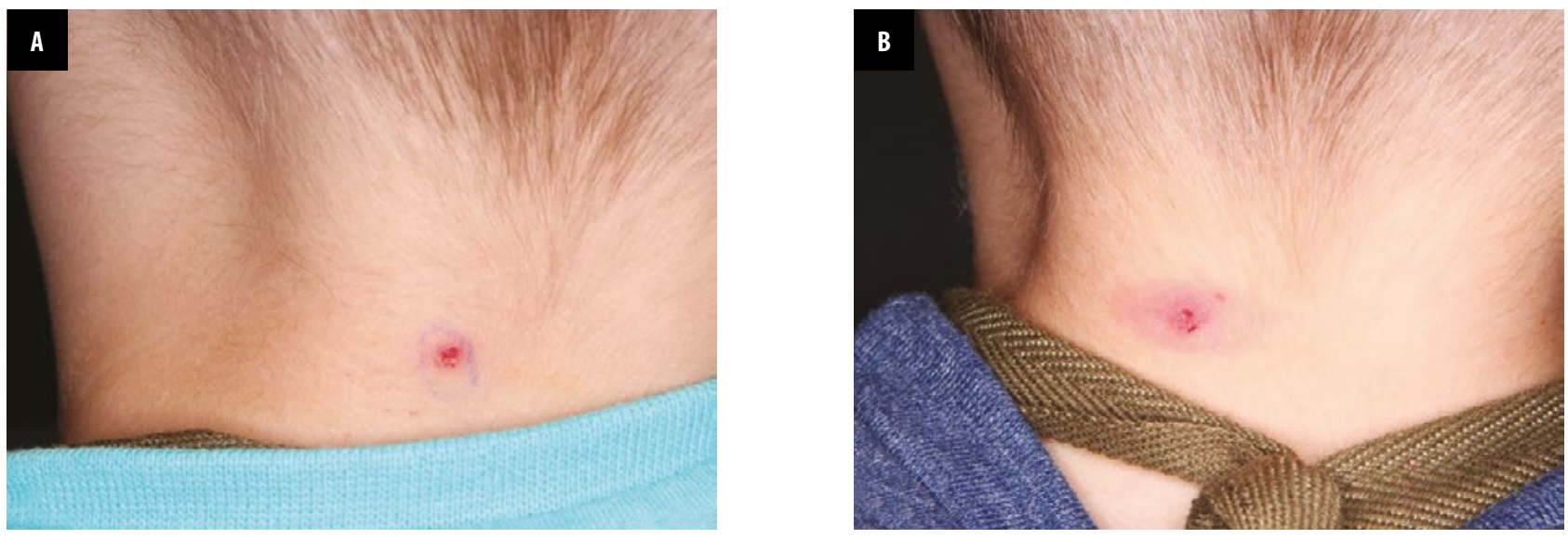

Fig. 2. Erosion on an inflammatory bed. Photographs taken on the $1^{\text {st }}(\mathbf{A})$ and $2^{\text {nd }}(\mathbf{B})$ day of acyclovir treatment 


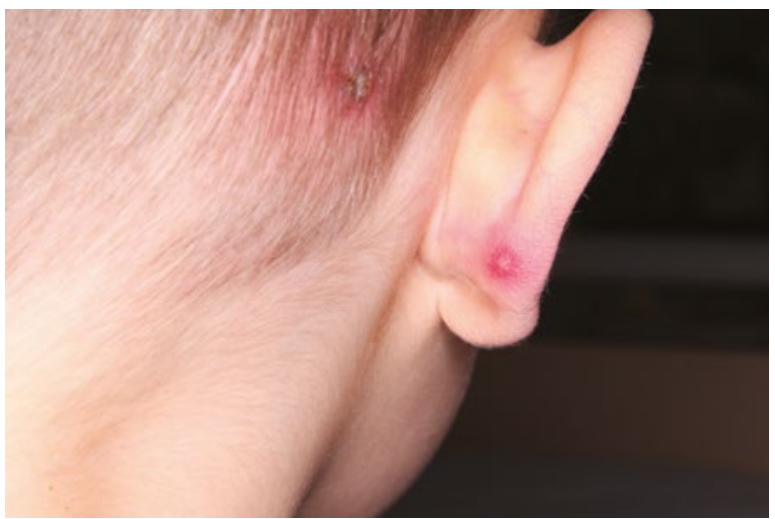

Fig. 3. A single vesicle on the auricle ( $2^{\text {nd }}$ day of acyclovir treatment)

a single vesicle filled with serous contents, which burst the next day with subsequent formation of erosion.

A smear was taken for culture testing from the skin lesion on the occiput; in addition, a smear was taken for a PCR (polymerase chain reaction) test for varicella from an erosion on the back of the neck (Fig. 2). While continuing steroid therapy, acyclovir and clindamycin treatment was started. On the next days of hospitalisation inflammation developed around the skin lesions (cf. Figs. 1 and 2) and pruritus occurred; on the right auricle a new single vesicle appeared (Fig. 3). The boy was afebrile and remained in a good general condition. A bacterial culture test on a smear taken from the skin revealed the growth of S. hominis, while PCR confirmed the presence of varicella-zoster virus (VZV).

The analysis of peripheral blood differential performed on the $8^{\text {th }}$ day of steroid therapy confirmed good response to treatment (absolute blast count of $<1,000 / \mathrm{mm}^{3}$ ), which was continued according to protocol. Isolation at the observation unit continued until all eruptions dried up, i.e. until the $11^{\text {th }}$ day from the appearance of the first skin lesion. Acyclovir treatment was conducted for 14 days in total.

After a month from the end of varicella the patient developed zoster involving left Th11 and Th12 dermatomes. The skin lesions were not accompanied by fever or pruritus and there was no hyperaesthesia before the appearance of eruptions. The boy remained in a good general condition. For this reason, and due to improving blood count and normal inflammation markers [C-reactive protein (CRP) $<0.5 \mathrm{mg} / \mathrm{dL}$ ] oral acyclovir was administered at $5 \times 800 \mathrm{mg}$ for 7 days in home settings. After 7 days of zoster treatment, when all skin eruptions were already dried up, chemotherapy was resumed.

\section{DISCUSSION}

Varicella is a very contagious disease, which is transferred by the airborne route or direct contact with an infected highest morbidity in the cool season: in late winter and in the spring in Poland. The clinical course of the disease depends on the patient's age, individual risk factors and the intensity of exposure to the virus. Although the disease usually has a mild and self-limiting course, serious complications may develop even in completely healthy individuals. In Europe, approximately $90 \%$ of children come into contact with varicella during the first 10-12 years of life $\mathrm{e}^{(1)}$. A live attenuated vaccine against varicella (administered in two doses) is available; it is characterised by a high efficacy ( $80 \%$ reduction of the risk of varicella and $>99 \%$ reduction of the risk of severe-course varicella) ${ }^{(2)}$. However, there are reports that in children with cancer the course of varicella may rarely be severe despite previous vaccination and the presence of anti-VZV antibodies ${ }^{(3-5)}$. The boy discussed in this paper was not vaccinated against varicella.

The clinical presentation of varicella in generally healthy children is characteristic enough for diagnosis to be possible without laboratory tests. The identifying features of this disease are mottled and papular eruptions evolving into vesicles (the image of "a dewdrop on a rose petal") spreading centrifugally (initially on the skin of the head and trunk, subsequently on that of extremities). The eruptions appear in series over 3 days, being, as a result, at different stages of development at a given point in time (a sign considered to be pathognomonic for varicella). The presence of eruptions on the scalp is typical; oral cavity mucosa and other areas may also be involved. The eruptions are usually associated with pruritus, fever and malaise, although the severity of these symptoms varies among the affected individuals ${ }^{(6)}$.

In immunosuppressed patients the diagnosis of varicella may be much more difficult. In children with ALL the course of varicella may be atypical and particularly severe $^{(4,7,8)}$. Before the era of antiviral therapy, in $1 / 3$ of children treated for leukaemia varicella affected internal organs (pneumonia, encephalitis, hepatitis) and $6.7 \%$ of children died of varicella complications ${ }^{(7)}$. What is particularly important is the fact that a progressive course of the disease with internal organ involvement may be associated with only a slight rash ${ }^{(9)}$. Unfavourable prognostic factors for varicella in children with ALL include abdominal or back pain preceding the appearance of skin eruptions and a low absolute lymphocyte count ${ }^{(10)}$.

In the boy reported in this paper, the course of varicella was very mild; the atypical morphology of the eruptions, a lack of pruritus, which appeared only after approximately 5 days of treatment, and the absence of prodromes and fever represented a diagnostic challenge. In such rare cases in which laboratory testing for VZV infection is necessary, the most sensitive and preferred method is PCR, which is used to examine material from a skin lesion, at best collected from the bottom of a ruptured vesicle, although crust may also be used for examination ${ }^{(11)}$. The material should be collected using a polyester swab. 
In the discussed patient there were no vesicles during material collection, therefore, a smear was taken from the bottom of an erosion using a swab dampened with $0.9 \%$ $\mathrm{NaCl}$. A positive result was obtained, which confirmed the diagnosis of varicella.

In a retrospective study including 697 children with ALL, 110 of whom had varicella, Hill et al. demonstrated that steroid therapy conducted in the period up to 3 weeks before the occurrence of varicella (i.e. in the incubation period) is associated with an increased risk of a severe course of the disease $\mathrm{e}^{(8)}$. The authors of the study suggest that in children treated for ALL who have come into contact with varicella, steroid therapy should be postponed by 21 days even if they have been vaccinated or received anti-VZV immunoglobulin (VZIG). However, patients in whom steroid therapy is needed to induce ALL remission and in whom delay of such therapy is associated with an increased risk of therapeutic failure are a special case. This applied to the patient reported in the present study, therefore, considering the mild course of the disease, the treatment, including steroid therapy, was continued according to protocol and remission was achieved despite the low absolute lymphocyte count.

Zoster is a clinical manifestation of VZV infection reactivation after a decrease in immunity against VZV, therefore, it is most common in the elderly. In the paediatric population zoster is observed primarily in patients with compromised immunity and in those who became infected with VZV during foetal development or their first years of life. The infection manifests as erythematous and vesicular eruptions whose location is consistent with that of dermatomes. The appearance of eruptions is often preceded by cutaneous hyperaesthesia. In immunosuppressed children the course of zoster may be much more severe, with generalisation, internal organ involvement and complications such as pneumonia, encephalitis, hepatitis or disseminated intravascular coagulation $^{(12)}$. However, one may presume that in the era of acyclovir therapy the clinical course of zoster in immunosuppressed children has become closer to that of their immunocompetent peers ${ }^{(13)}$. In a study involving 90 children with ALL who developed zoster Sørensen et al. demonstrated that there were no internal organ involvement or deaths among children receiving oral acyclovir $^{(14)}$. This is particularly important since intravenous acyclovir therapy is associated with an increased risk of complications (e.g. acute kidney injury) and hospital-related infections. Based on the circumstances mentioned above and the mild course of the disease in the boy, a decision was made to administer oral therapy in outpatient settings, with a good clinical outcome.

In summary, one may conclude that VZV infection in children with ALL may pose a diagnostic challenge. In this group of patients one should suspect varicella based on epidemiological data and contact with an infected individual in the disease's incubation period.
The appearance of any eruptions or abdominal or back pain should raise the suspicion of varicella, which should be confirmed with viral testing. Simultaneously, acyclovir treatment should be started. The diagnostic method of choice is PCR. The anticipation for the result should not delay intravenous acyclovir treatment and post-exposure prophylaxis in individuals who have come into contact with the infected individual, particularly other children with ALL. Uncomplicated zoster in children with ALL may be treated with oral acyclovir. The decision to continue chemotherapy in children with ALL infected with VZV should be taken on an individual basis by an experienced team of specialists in paediatric haematology and oncology in collaboration with infectious diseases specialists.

\section{Conflict of interest}

The authors do not report any affiliations of any nature to any persons or institutions that could claim to have rights to the above paper or affect the statements presented therein. 


\section{References}

1. Sengupta N, Booy R, Schmitt HJ et al.: Varicella vaccination in Europe: are we ready for a universal childhood programme? Eur J Pediatr 2008; 167: 47-55.

2. Marin M, Marti M, Kambhampati A et al.: Global varicella vaccine effectiveness: a meta-analysis. Pediatrics 2016; 137: e20153741.

3. Yamada M, Kamberos N, Grose C: Breakthrough varicella in a cancer patient with persistent varicella antibody after one varicella vaccination. J Pediatr 2013; 163: 1511-1513.

4. Kriner P, Lopez K, Leung J et al.; Centers for Disease Control and Prevention (CDC): Notes from the field: varicella-associated death of a vaccinated child with leukemia - California, 2012. MMWR Morb Mortal Wkly Rep 2014; 63: 161.

5. Manley S, Mallinson $\mathrm{H}$, Caswell $\mathrm{M}$ et al.: Chickenpox in varicella IgG positive patients: experience of a regional paediatric oncology centre. Pediatr Blood Cancer 2008; 51: 540-542.

6. Paller AS, Mancini AJ: Exanthematous diseases of childhood. In: Paller AS, Mancini AJ: Hurwitz Clinical Pediatric Dermatology. A Textbook of Skin Disorders of Childhood and Adolescence. $5^{\text {th }}$ ed., Elsevier, 2016

7. Feldman S, Hughes WT, Daniel CB: Varicella in children with cancer: seventy-seven cases. Pediatrics 1975; 56: 388-397.

8. Hill G, Chauvenet AR, Lovato J et al.: Recent steroid therapy increases severity of varicella infections in children with acute lymphoblastic leukemia. Pediatrics 2005; 116: e525-e529.
9. Rowland P, Wald ER, Mirro JR Jr et al.: Progressive varicella presenting with pain and minimal skin involvement in children with acute lymphoblastic leukemia. J Clin Oncol 1995; 13: 1697-1703.

10. Kim SK, Kim MC, Han SB et al.: Clinical characteristics and outcomes of varicella zoster virus infection in children with hematologic malignancies in the acyclovir era. Blood Res 2016; 51: 249-255.

11. Centers for Disease Control and Prevention: Collecting Specimens for Varicella Zoster Virus (VZV) Testing. 2017. Available from: https://www.cdc.gov/chickenpox/lab-testing/collectingspecimens.html.

12. Paller AS, Mancini AJ: Viral diseases of the skin. In: Paller AS, Mancini AJ: Hurwitz Clinical Pediatric Dermatology. A Textbook of Skin Disorders of Childhood and Adolescence. $5^{\text {th }}$ ed., Elsevier, 2016.

13. Kuchar E, Szenborn L, Lis I et al.: Clinical presentation of herpes zoster in immunocompetent and immunocompromised hospitalized children treated with acyclovir. J Pediatr Hematol Oncol 2016; 38: 394-397.

14. Sørensen GV, Rosthøj S, Würtz M et al.: The epidemiology of herpes zoster in 226 children with acute lymphoblastic leukemia. Pediatr Blood Cancer 2011; 57: 993-997. 